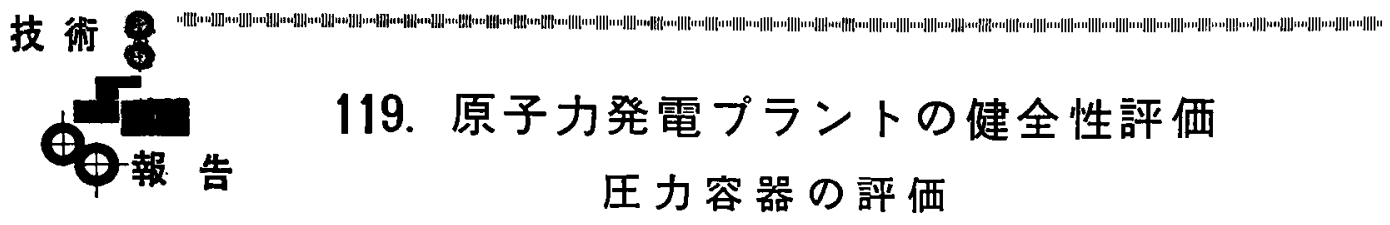

藤 村 理 人*

\author{
（1983年 7 月12日 受理） \\ (1983年 12月14日 再受理) \\ Integrity Assessment for Nuclear Power Plants \\ Pressure Vessel
}

By Tadato FUJIMURA

"

It is required to minimize qualitatively the radiation exposure for the public or nuclear employee in the cases of the normal operation and any accident of the nuclear power plant. Dr. Hideo Uchida, a member of Nuclear Safety Commission of Japanese government, has proposed a personal draft of acceptance criteria for the radiation damage, based on the magnitude of nuclear accident and its occurrence probability.

On the other hand, for example, it is not clear what category of hardware damage in the nuclear plant corresponds to an event of 5 rem-exposure-damage, which has been recognized to classify to a small break loss-of-coolant accident (SBLOCA), and its occurrence probability is the order of $10^{-4} /$ reactor $\cdot y r$.

In this paper, the author has tried to connect radiation damage to the hardware damage by interposing the failure probability of the nuclear pressure vessel.

Recently, the assessment of the structural integrity for the nuclear pressure vessel has become one of the most important problem for the assurance of the nuclear safety. The author has discussed pressurized thermal shock (PTS) issue in this context and proposed new position in the assessment of structural integrity for the nuclear power plant.

KEYWORDS: structural integrity, reactor pressure vessel, pressurized thermal shock, irradiation embrittlement, nuclear power plants, nuclear safety, radiation damage failure

\section{I. 問題提起}

従来, “As low as practicable”といった定性的な概念 によって，原子妒定常運転または事故時の放射線被曝 を最小限に抑制することが原子力発電プラントの安全 性を確保する上に要求されてきた。内田は，発生する と想定される“事故の大きさ”と事故の“発生確率” の見合いで評価することによって，原子力発電プラン トの安全性を評価すべきであると主張していた(1)。 の主張は，原子カプラントの安全性評洒の手法として 合意されている。しかしながら，その目安をとのよう に決定するかによって, 安全性評価の基準の妥当性が 問われることになる。

すなわち，原子力発電所の安全基準として，多数の 被贵者が出るような事故はいかなる小さな確率でる容
認できないが，一方，技術的手法による重大事故発生 確率をゼロと評価することもできない。そこで，構造 健全性を確保する観点からは, $10^{-6} /$ (炣.年)とか $10^{-7} /$ （炉・年）といら確率を，重大事故発生の抑制のため設 定することになる。ここで $10^{-6} /($ 炉・年)とい5発生確 率の社会的意義は，来たる21世紀に纱いて，地球上で 10,000基の原子力発電プラントが運転されていると考 えるとき，100年に 1 回，大事故が起きる確率に刘応 するといえる。いいかえれば，人間80年の寿命で，世 界のどこかで 1 回，被害者数万の規模の事故を経験す ることが許されるか,ということに等しい。しかし、こ れではパブリック・アクセプタンス(PA)は得られない

* 高温構造安全技術研究組合(ISES; Tech. Res. Assoc. for Integrity of Struct. at Elevated Temp. Service) 
として, 規制面*では $10^{-7} /$ (炉.年)といら重大事故発生 確率を原子力発電プラントの安全性確保の目標とし， 1,000年に 1 回の重大事故の経験ならば,まず原子力発 艃所の安全性に䍕問をむつ公衆はないであろうと一般 に合意されている。

現在の原子力技術は重大事故の発生確率を $10^{-7} /$ (炻 ・年)に刎制できるほと進歩していない。現在はたかだ か10-6/(炬・年)を確保しているに過ぎないであるら。 その根抛は後述するとして, 現在の技術レベルで， 1979年アメリカで起きたTMI-2 号炻の事故を評価す ると, TMI 事故は過去に㧍ける原子力発電所の最大事 故であり，しかも世界における原子力発電プラントの 運謓経験が $10^{2}$ (炬・年)に過ぎない時点において発生し たのであるから，単純にはその発生確率は10-3/炉. 年)となる。るしこの事故の被害者が数万人にのぼる ことがあったならば, 原子力発電プラントは全面的に モラトリアムされたと思われるが，幸いにも住民への 放射能災害は発生していない。

\section{II . TMI-2 号炉の事故についての 構造機器の健全性評価}

軽水师原子力発電所の事故の原因は，(1)多重安全防 證系の不完全と，(2)運転員の操作末熟といわれてい る(2)。原子炉事故はまかり間違えば，死者数万人に及 ぶ要因をるっている。しかしながら，TMI 事故に稀け る重大事故への発展の防止は, 第 1 に格納容器内に事 故をとどめたこと，第 2 に压力バゥンダリーの損傷が なかったこと，による。もし圧力バウンダリーが重大 破損状態に発展していたならば，公衆に重大な影諳を 与克，放射能が大気中に㹡散するに至ったかるしれな い。逃し弁の開放故障が起きてはいるが，これは本質 的に坆射能污染につながるるのではなかった。

このような TMI 事故は，原子炉の廃却に追い込む 乖故，すなわち，第 1 表に示すレベル事故であっ たのか，それとも修復して運転可能なレベルII属寸 る事故であったのか著者は注目してきたが，現在では， プラントの再稼働が可能であっても，それは相当先の 時期であって，プラントの状態は全般的にはレベル III の事故といえよう。しかしながら、ハードェて，特 に圧力バゥンダリーと呼ばれる1次冷却材を閉じ込め る機能を果たす圧力容器, 配管, 蒸気発生器などは, 大 きな損鹪がなく，レベルIIの状態の事故と琹めること ができる。

TMI 事故では, 圧力バゥンダリーの損傷はレベル II であったこと，また格納容器棈造は損傷を受けていな
第 1 表 原子力発電プラントの健全状態区分

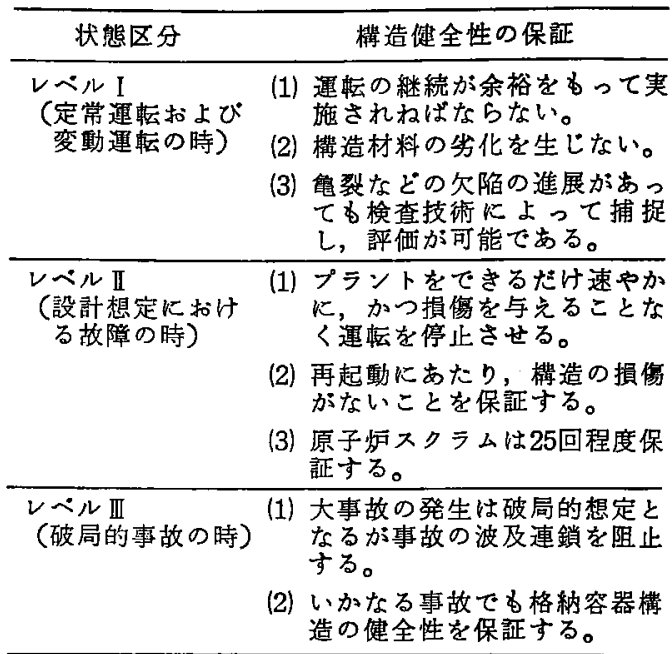

いことから，構造健全性の専門家は原子力発電プラン トの設計手法に間違いのないことに自信を深めた。も しも,これらの機器に重大破損が起きていたときは, 現在の原子カプラントの構造設計思想は根底から覆さ れ，材料の選択から構造設計，施工执よび検査まで全 面的に見直さねばならない。その理由は，現在のハー ドウェアの重大破損が起きる確率は $10^{-6} /($ 炉・年)に 過ぎないとして，原子カプラントの構造健全性を主張 してきた構造設計手法が神話として崩㐭し，現実には 1,000倍高い確率で重大破損事故が起きたことになる からである。

\section{III. 原子炉圧力容器の健全性}

原子力発電プラントに拈いて，原子炉压力容器は核 然料炻心を内蔵し，核分裂反応を制御しながら進行せ しめて熱エネルギーを取り出す重要な構造である。こ の圧力容器が重大破損をすることがあれば，他の機器 のよらに安全防護をすることは困難である。換言すれ ば，圧力容器に重大破損が発生すれば原子力発電所の 構造健全性を保証することは不可能になる。すなわち, 事故の波及連鎖を防ぎ，格納容器を損偒せしめない保 証をすることが極めて難しいと考えられるからであ る。ここに，圧力容器の設計と設計条件が特別に保守 的にならざるを得ない論拠がある。

* NRC, Stadard Review Plan では発生事故の確率の 総計で規制している。しかし，圧力容器のような 重要棈造物では，単独で低い破損確率を確保しな ければならない。 
第 1 図*では，横軸にブラント機器の供用経験を(基 数 $\times$ 供用年数)で表わし，縦軸にプラント 1 (基・年)** 当りの重大破損の発生確率を示している。その実線で 示す傾向は, 原子力用以外の青置機器と呼ばれる圧力 容器, ボイラなどについて求めたるので，回転機械，才 なわちポンプ,タービンなどの破損確率はもう 1 标，す なわら10倍高い10-4/(基·年)である。ちなみに, $10^{-5} /$ (基·年)といら破損確率は 10,000 基の容器が10年稼働 した供用経験において，1 基が重大破損を起こす確率 である。原子力機器以外の圧力容器などでは現在, 供 用経験は $10^{\circ}$ (基·年)を超えていて，その重大破損確率 は10-3/(基·年)となっている。プラント・エンジニフ リングでは，供用経験が進むに従い技術の進歩と経験 が相まって, 事故確率は低下し, 第 2 次大戦前に比べ て現在では，その破損確率は注ば1/10亿低下している。

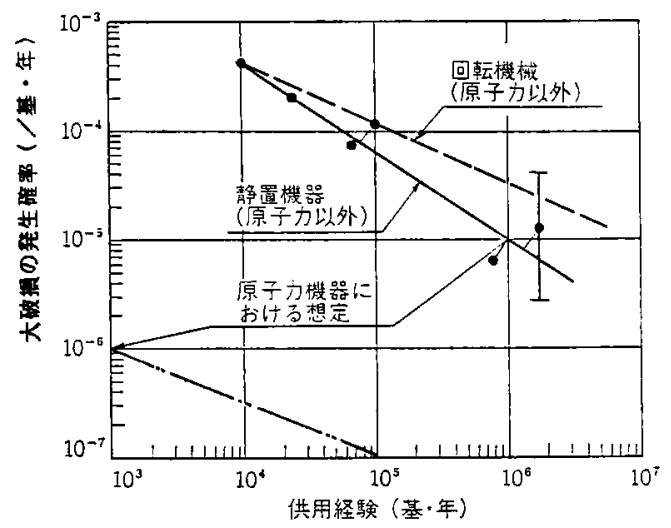

第 1 図機器の大破損発生確率

原子力発電プラントは現在世界でほぼ250炉が稼働 しているが，その経験は 1,000 (炉・年)を超えたところ で, 原子力以外のボイラ, 圧力容器の $1 / 1,000$ の経験に すぎない。原子カプラントと原子カ以外のブラントを 比較すれば，前者は明らかに品質保証手段が進んでお り，最高の現代技術を駆使している原子カプラントの 構造では重大破損確率は 1 标( $1 / 10)$ 低いと考えられて

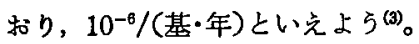

原子力技術は原子力以外のボイラ, 圧力容器技術を 基礎にして発展したすのであるが，技術革新が著しく 進んでいる現在では，第 1 図に示したように，破壊確

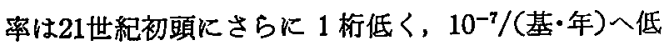
下するであろ5。現在より 40年後の 2020 年において, 世界の原子力発電所の数が5,000基になると想定すれ ば，その供用経験年数は，おそらく200,000(基·年)程 度になろう。この時点に和いても, 圧力容器の重大破
損事故が 1 回も発生しない確率が $5 \times 10^{-8} /$ (基・年)以

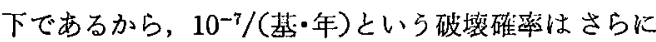
その $1 / 2$ 以上小さく，破液に対して極めて大きな余衳 をるっているといらことができる。

\section{IV. 技術的努力}

原子力発電プラントの安全性は压力バウンダリーの 健全性に依存するところが大きい。そのうえ原子炉压 力容器が破損するようなことがあれば，王力容器を大 きく修理したり，交換することはまったく不可能なの で, 原子力ェネルギー利用の経娍性は成立しなくなる。 そのう充王力容器の破損は，原子力発電プラントの多 重防御の思想自体が崩壤することになる。想定される 圧力容器の重大破損の状態は，いわゆる鋼材の不安定 破坮と呼ばれる破流モードである。このような急速な 破壤モードでは，破壤回避または応急処置のため，ブ ラントの緊急停止により内王をたは温度を下げたり， 運転員が退避したりするに必要な時間の余裕がまった くなく，数秒，数分の単位で事故は桩大すると考光ら れる。

このため, 不安定破境を防止するための圧力容器の 設計製造技術の手順と，供用に拈ける健全性評価手順 は極めて保守的になっている。

\section{1. 圧力容器の設計}

圧力容器に使用する鋼材には強度よりる勒性を強く 要求している。靶性とは，材料の表面に亀裂性欠樎が あったとしても破塤に対する抵抗が高いことをいう。 これは先に述べた不安定破壊を防ぐために必要であ る。フェライト鋼材は脆性破㙲遷移温度をもってい て, その温度以下では勒性を失う。压力容器は靸性を 失わない状態で製造て，供用することが，構造設計の 第 1 原則である。よく知られている $R T_{\text {NDT }}$ といら温度 は，この脆性破壊要移温度を保守的な試験方法で評価 して定めた設計上の圧力容器の供用下限温度として定 義される。 $R T_{\mathrm{NDr}}$ にさらに余裕をるたせた温度条件 で供用することが，圧力容器の重大破損を防ぐ必須の 条件となっている。

ここで注意しなければならないことは，材料はすべ て溶接部を含む議論であって, 溶接部の鞀性は母材と 同等またはそれ以上であることが必要である。

*文献(3)および(4)上り編成した。

**運転経鈳性原子师当りとすれば(炉・年)となり，圧 力容器当りとすれば(基・年)または(ベッセル・年) と呼ぶべきであろう。 


\section{2. 圧力容器の製造}

王力容器は溶接施工, プレス成形と熱好理によって 製造される。製造された圧力容器は40EFPY(全出力 実効換算年)の供用期間に破損を生ずることがないこ とを保証して，欠宿のない容器として供給される。具 体的には，鋼材は材料会社から製造会社に無欠陥の材 料として供給されている。ここで述べる“無欠陥”とは， 表面きずについては規定の手直しをし，鋼材内部のき ずについては規定の非破壊検査による，判断基準に基 つ力学的欠宿(主として表面の龟裂性欠楩)がないと いらことを確認した状態をいう。判断基準以下のき ず*の存在は記録され許容される。完全に無きずの材 料はあり得ないし，そのよらな材料の製造を要求した ならば，材料の廃却がふえてプラントの経済性は成り 立たない。また中性子照射脆化による破壊防止のため の現実的処置としては，炉心に近い容器シェルのため には特にきずの少ない材料が確保される。

王力容器の製造工程では, 溶接継手の品質保証が重 点であり，検査の全数実施上多重の検查は原子力機器 の製造において初めて工業的に奏施された品質保証技 術である。全数検查の原則は、「構造は補修または部分
的廃却をすることによって無欠陷構造をつくることが 可能である」という思想に基づいている。

このよらにして，最新の検查技術を駆使した限界に 扣いて，合理的判断のもとに“無欠陉”と認識できる珐 力容器が供用されている。

\section{V. 破壊確率論による技術努力の評価}

第 1 図で述べたように，原子力以外のプラントの構 造の重大破損確率は， $10^{6}$ (基·年)の供用経験を経て， $10^{-5} /$ (基·年)であると考えられる。

供用経験による破損確率の低減は次式より計算され ている(4)。

$$
\lambda_{\iota}=(1-\alpha) \lambda_{\Sigma}
$$

$こ こ て ゙, \lambda_{t}:$ 将来の破損確率

$\lambda_{\Sigma}:$ 靦在の破損確率

$\alpha$ : 技術努力および供用経験 $(0.3 \sim 0.5)$

この低減は技術の進歩, 運転経験による習熟, 安全防 護設備の充実などの総合化によるるのである。第 2 図 は第 1 図をるとにして作図したものであるが，最近， 圧力容器の重大破損に対して見直しが迫られている。

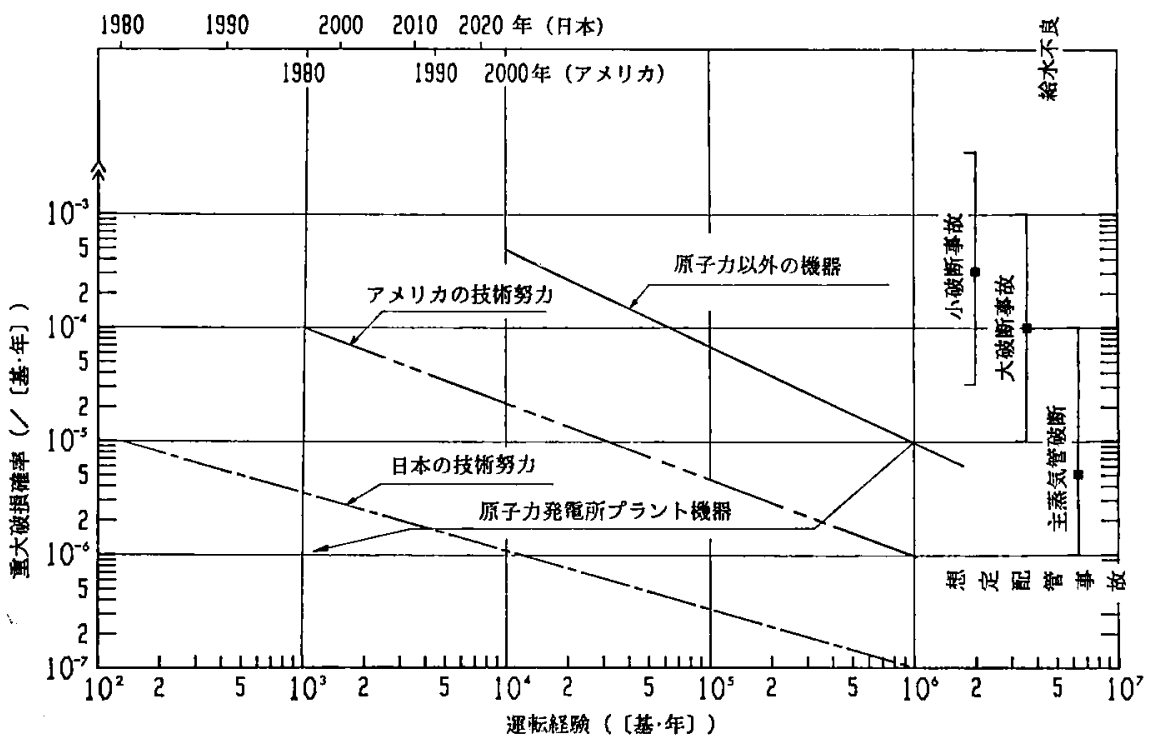

第 2 图原子力発電プラントの技術努力

従来, 原子力発電プラントの安全解析において, 主要 配管の瞬時破断が想定されてきたが，王力容器の破損 は考感されておらず，圧力容器の健全性論議は棚上げ されていた。これは，前述したように，原子炉圧力容 器の重大破損確率は $10^{-8} /$ (基·年)であると信頼してき
たことによるが，最近，新たに生力容器に対する加圧 熱荷重(Pressurized Thermal Shock, PTS)問題がクロ

* 久陥ときずは用語を区別して使用した。欠楩の存 在は高級なプラントでは許されないが，きずは存 在が許される。 
ーズアップされて，見直しが必要となっだ(5)

この加圧熱荷重問題の破壊確率諭からみた重要性は 次のとおりである。

(1) 原子カプラント特有の現象として認識されて いる鋼材の照射脆化がかかかっている。

（2）システム事故，例えば大口径配管 破断，小口 径配管破断，主蒸気管破断または給水不良状態 により王力容器に熱水力過大荷重が加わること がある。

（3）熱衝撃荷重により王力容器内面のきずから不 安定亀裂を発生する可能性がある。そのきずの 大きさが非破壞検查検出限界以下でも亀裂の発 生の可能性があり，亀裂伝播阻止特性を重視し なければならなくなってきた。

以上の項目について, 圧力容器の健全性評価は従来 実施されていない事項であった。

米国原子力規制委員会 (USNRC) によれば，PTSに よる王力容器の重大破損確率は $10^{-4} /$ (基・年) と評価し ている(8)。この確率はわれわれが信じていた $10^{-6}$ /(基 ・年)の100倍であり，アメリカで $10^{3}$ (炉・年)の供用経 験のるとで余裕度10倍という厳しい確率とい圭よう。 しかし，これらの敩しさをもっている原子力発電プラ ントは第 I および第 II世代*のプラントであるから，

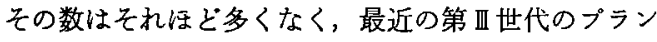
トでは加圧熱荷重にほとんど問題がないと著者は推测 しているが，アメリカでは1980年に压力容器の健全性 を見直すことが必要になり，1982年に報告がまとめら れた。日本では1980年時点での原子カプラントの供用 経験は150(犵・年)であるが，フメリカより高品質の鋼 材を使用し, 原子炉王力容器の破損確率は $10^{-5}$ (基・年) 以下と著者は考えている。すなわち、アメリカより破 損確率が1/10低い。

しかしながら，日本の技術的努力の目標は2000年に 向って $10^{-6} /$ (基・年)にする必要がある。2000年には日 本の原子カプラントの供用経験が 1,200 (炬・年)に伸び るが，その之き原子力発電所の重大破損確率は，第 2 図に示したよ5に $3 \times 10^{-6} /$ (妒・年)まで低下するであ ろう。このよらな日本の原子炉王力容器の技術的努力 の現状の認識について, 品質過剩と見るか, 健全と見 るかは, 一般公采の安全性の判断にかかっている。

\section{VI. 内田提案と圧力容器の健全性確保}

第 3 図は，安全性評価に関する内田提案に圧力容器 重大破損を参照せしめて作図したるのである。同図の 縦軸火重大破損確率をとり，横軸の上段は放射線個
人被曝線量, 下段は圧力容器の脆性破壞基準温度 $R T_{\mathrm{NDT}}$, すなわち压力容器鋼材の照射航化度をとった るのである。抄軸の上段と下段のスケールは対応する ものではないが，重大破損確率を介して両者の関連を 評洒することができる。例えば，TMI 事故は10-3/ (炉・年)の確率で起こり, 個人の放射線被懪は0.1 rem であった。この事故の状態を小日径破断(SBLOCA) と することに疑問があるが, SBLOCAの発生確率とTMI 事故の発生確率とは同等であった。一方, SBLOCA 引き金として，圧力容器の重大破損発生確率は，正力 容器の内面の $R T_{\mathrm{NDT}}$ の上昇が大きいとき，すなわら 照射脆化度が大きい場合 $5 \times 10^{-4}$ /(基·年)に達する**。

USNRC では従来, 圧力容器の $R T_{\text {NDT }}$ は $200^{\circ} \mathrm{F}(93$ $\left.{ }^{\circ} \mathrm{C}\right) に$ 規制していた(9)。すなわち，この規制温度を超え た場合，運転を停止して照射脆化を低減する処置をと ることを要求していた。この規制では加圧熱荷重によ

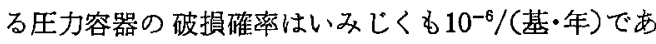
った。しかしながら，最近の第 I 世代圧力容器の照射 脆化の進展は大きく，中性子照射による $R T_{\mathrm{NDT}}$ の上 限規制を最近 $270^{\circ} \mathrm{F}\left(132^{\circ} \mathrm{C}\right)$ に改めることにした。これ は，第 3 図で明らかなよらに，压力容器の破損確率を $2 \times 10^{-4} /$ (基·年)までゆるめたことになる。この処膡 の理由については，アメリカの原子力発電プラントの 供用経験が2000年においてようやく $10^{4}$ (炉・年)に達す ることを考感し，第 2 図に示したように，今後の技術 努力と供用経験により，破損確率が $3 \times 10^{-5}$ (基·年)に 低下し, その健全性裕度はほぼ 3 となるので, 王力容器 の重大破損事故は回避できると著者は解釈している。 このような確率論的てプローチのみで, 王力容器の重 大破損が回避できるかどうかは厳しい問題で, 現在, 決 定論的方法による研究計画がアメりカで大規模に展開 されている。

原子力安全委員会の内田委員は，1983年春の日本原 子力産業会議の大会で，原子力発電所の安全性確保の 定量的目標として，個人被曝が $5 \mathrm{rem}$ に達する事故 は，その発生確率は $10^{-4} /$ (炉・年)と評洒している。こ こに $5 \mathrm{rem}$ 事故が，原子炉構造に拈いてどのような其 体的な破損状沉に対応するかが構造健全性における課 題である。

SBLOCA はこの確率で起きる可能性がある。SBLO CA で事故の規模を格納容器内にとどめれば，5 rem

* 圧力容器に使用される銅材の成分規制の改定によ って世代を分けているか，鋼材の製造時点と圧力 容器の製造時点では数年の時期のズレがある。

** SBLOCA と連動してPTS 事故が起きる確率。 


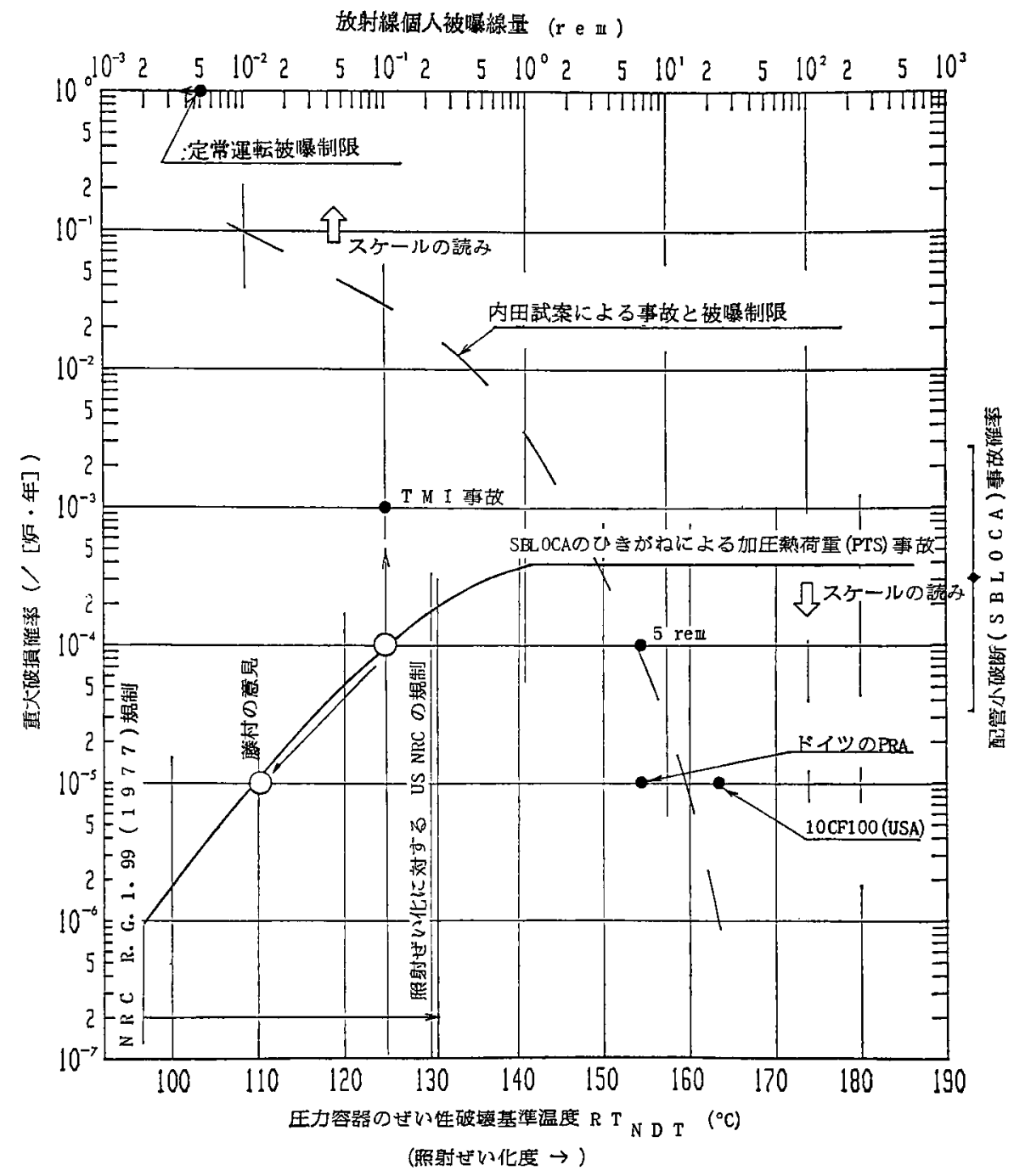

第 3 図 原子炉圧力容器の重大破損確率と故射線被曝

以下の被曝で事故を収束できると思われる。しかし SBLOCA を引き金にPTSによる圧力容器の重大破損 が連鎖発生したならば, $1,000 \mathrm{rem}$ 事故へと発展する 可能珄もある。ここに事故の連鎖を防ぐことがいかに 重要であるか認識しなければならない。

内田試案を遵守するためには，まず第 1 に主配管系 の漏洩先行型破損(Leak-before-break, LBB) 概念を実 証し，第 2 に日本ではSBLOCA の発生確率が $10^{-4}$ / (炉・年)より低いことを明らか炕することが重要であ る。そして, SBLOCA K連動する加圧熱荷重による圧 力容器の破提確率は $10^{-5}$ /(基・年)であることを保証す るためには，RT $R T_{\text {NDT }}$ の制限を $110^{\circ} \mathrm{C}$ に制限することが
望ましいと著者は主張したい。

以上の確率論的健全性評価に加えて, 決定論により 原子炉圧力容器の健全性を保証するために, 加圧熱荷 重による圧力容器の重大破損は次のようなシナリオで 防止できることを確認しなければならない。

(1) 第 I 世代圧力容器の内面にきずが存在する部 材が，高速中性子照射を $1 \times 10^{19} n / \mathrm{cm}^{2}(>1 \mathrm{MeV})$ 以上受けたとき，安定龟裂を発生する可能性が あるが，その龟裂発生確率は $10^{-5}$ /(基・年)以下 であることを確認する。

（2）発生したとする不安定亀裂は極めて速い速度 で伝播するが，鋼材の不安定重裂停止特性によ 
って板厚の中で停止することを確認する。この 亀裂停止特性についてはまだ十分な確証を得ら れていないので，研究開発によって数量的に把 握する。

（3）停止した不安定亀裂は供用によって延性龟裂 として遅い速度で進展寸る可能性があるが，そ の速度は十分に小さく，原子炉供用期䦓中の監 視(ISI, In-service inspection)によって捕捉し， かつ十分な評価時間を有し，重大破損に至らな いで原子炉を停止できることを確認する。

すなわち，以上のようなシナりオにより，圧力容器 といえどむ漏沂先行型破損(LBB)概念が成立すること を配管系と同様に確認できる。しかしながら，圧力容 器は配管系以上に供用の保守性が要求されるので, LBB 概念は安全裕度として保留しておくことが望ま しい。

\section{VI. あとがき}

本論文は，原子力発電プラントの健全性論議が，安 全解析の専門家間にととまらず，広く原子力開発分野 に护る研究者, 技術者の参加により呼び起こされる ための一石として書いたものである。
本論文の未熟な点については読者にご指摘を頂き, さらに潹く，定量的な議論をするとともに，わかり易 い言葉による一般公鼻の原子力プラントの安全珄の理 解の一助となることを希望して筆をおく次第である。

\section{一考文献一}

(1) 内田质雄: 安全をめぐる諸問題(原子力施設の安全問題特 集の5ち), 原子力工業, 19[9], 12 (1973).

(2) 原子力安全委員会, 日本学術会議編: “学術シンポジウム, 米国スリー・マイル・アイランド原子力発電所事故の提起 乙た諸問題·報告書”，(1980)，大蔵省印刷局.

(3) The Advisory Committee on Reactor Safegurds: Report on the integrity of reactor vessels for light water power reactor, Nucl. Eng. Design, 28, 147 195 (1974).

(4) BUSH, S.H.: Probability of damage to nuclear component due to turbine failure, Nucl. Safety, 14 [3], 31 72 (1973).

（5）藤村理人：原子炉の圧力容器に破填はあるか，原子力工 業, 29[2, 4], 9 (1983).

（6）矢川元基：原子力圧力容器の健全性に関する最近の課題 -PTS 問題を中心K，同 上，30[1]，61 (1984).

（7）三岛良皘，藤村理人：原子炉王力容器に関する最近の話題 (1), 同 上, 30[3], 60 (1984).

(8) NRC Staff Evaluation of Pressurized Thermal Shock, Draft, (1982).

(9) U.S.NRC: Regulatory Guide, 1.99, (1977).

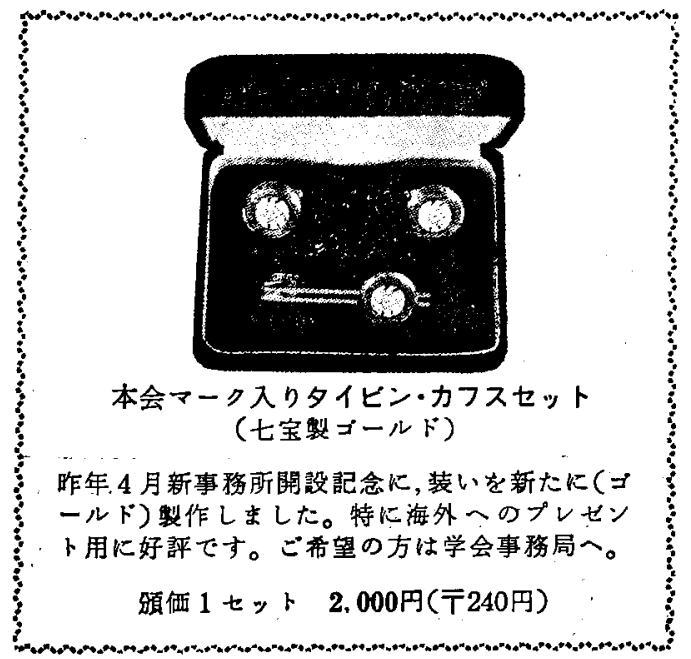

第 3 回法政大学イオンビーム工学シンポシウム

$$
\text { 電子デバイスとイオンビーム }
$$

主 催 法政大学イオンビーム工学研究所

期 日 1984年12月 7 日(金)，8日（土）

場 所 法政大学工学部(国電中央線 東小金井歌下事, 徒步12分)

内容電子デバイス製作プロセス技術へのイオンビーム利用

(1)イオンビーム加工技囝

(2)イオンビームによる物性制御

(3)イオンビーム利用に関連したデパイス特性向上

(4)イオンビームを利用した䇲価技葕

(5)その他

講演時間 1 件約20分(予定)

譵演申込楴切所定申込用紙に記入の上，9月22日（土）て と下記申込先へお申し込み下さい。

\section{参加要領 請演会参加富は無料}

資料は実費領布（当日会場受付）

問合せ·申込先 (广184)東京都小金井市根野町3-7-2 法政大学イオンビーム工学研究所 (Tel. 0423-81-5341, 内楾610 612) 